\title{
Extraction and Application of Laccases from Shimeji Mushrooms (Pleurotus ostreatus) Residues in Decolourisation of Reactive Dyes and a Comparative Study Using Commercial Laccase from Aspergillus oryzae
}

\author{
Ricardo Sposina S. Teixeira, ${ }^{1,2}$ Patrícia Maia Pereira, ${ }^{1}$ and Viridiana S. Ferreira-Leitão ${ }^{1}$ \\ ${ }^{1}$ National Institute of Technology, Ministry of Science and Technology, Avenue Venezuela, 82 Centro, \\ 20081-312 Rio de Janeiro, RJ, Brazil \\ ${ }^{2}$ Laboratory of Enzyme Technology, Chemistry Institute, Federal University of Rio de Janeiro, \\ Avenue Athos da Silveira Ramos 149, Bloco A, Itha do Fundão, 21949-900 Rio de Janeiro, RJ, Brazil
}

Correspondence should be addressed to Viridiana S. Ferreira-Leitão, viridiana.leitao@int.gov.br

Received 11 August 2010; Revised 10 September 2010; Accepted 5 October 2010

Academic Editor: Roberto Fernandez Lafuente

Copyright (C) 2010 Ricardo Sposina S. Teixeira et al. This is an open access article distributed under the Creative Commons Attribution License, which permits unrestricted use, distribution, and reproduction in any medium, provided the original work is properly cited.

\begin{abstract}
Oxidases are able to degrade organic pollutants; however, high costs associated with biocatalysts production still hinder their use in environmental biocatalysis. Our study compared the action of a commercial laccase from Aspergillus oryzae and a rich extract from Pleurotus ostreatus cultivation residues in decolourisation of reactive dyes: Drimaren Blue X-3LR (DMBLR), Drimaren Blue X-BLN (DMBBLN), Drimaren Rubinol X-3LR (DMR), and Drimaren Blue C-R (RBBR). The colour removal was evaluated by considering dye concentration, reaction time, absence or presence of the mediator ABTS (2,2' -azino-bis(3-ethylbenzothiazoline6-sulfonic acid), and the source of laccase. The presence of ABTS was essential for decolourisation of DMR (80-90\%, 1h) and RBBR $(80-90 \%, 24 \mathrm{~h})$ with both laccases. The use of ABTS was not necessary in reactions containing DMBLR $(85-97 \%$, $1 \mathrm{~h})$ and DMBBLN $(63-84 \%, 24 \mathrm{~h})$. The decolourisation of DMBBLN by commercial laccase showed levels near $60 \%$ while the crude extract presented $80 \%$ in $24 \mathrm{~h}$.
\end{abstract}

\section{Introduction}

In the textile industry, reactive dyes have been commonly used due to their advantages such as better dyeing processing conditions and bright colours [1]. The reactive dyes also exhibit a wide range of different chemical structures, which are primarily based on substituted aromatic compounds and heterocyclic groups [2].

Wastewater from dyeing industries has recalcitrant compounds and presents low biodegradability in conventional biological treatment plants. Biological processes are sensitive to shock loads and require long hydraulic retention times. These processes also form large amounts of solid residues and provide low efficiency in colour removal [3-5]. Earlier studies considered the combination of biological and enzy- matic treatment aiming for the reduction of organic matter and decolourisation, respectively $[6,7]$.

White-rot fungi have attracted increasing attention. Many studies showed that their ligninolytic enzymes have the ability to degrade recalcitrant compounds; therefore, they are able to decolourise different classes of industrial dyes [815]. Pleurotus ostreatus is a white-rot fungus that produces a ligninolytic enzyme complex rich in several laccase isoenzymes [16]. Laccases (EC 1.10.3.2) are phenol oxidases that catalyse one-electron oxidation of many aromatic substrates (polyphenols, methoxy-substituted monophenols, aromatic amines, etc.) with the concomitant reduction of $\mathrm{O}_{2}$ to $\mathrm{H}_{2} \mathrm{O}[17,18]$. The interest in laccases for biotechnological applications increased with the discovery of their ability to oxidize high-redox-potential substrates in the presence 
of synthetic mediators [19], which allows an extended substrate range of laccases [20]. The ABTS $\left(2,2^{\prime}\right.$-azino-bis(3-ethylbenzothiazoline-6-sulfonic acid) is often used as a carrier of electrons in reactions mediated by laccases $[14,16$, $18,21,22]$.

Laccases are very promising as environmental biocatalysts, and some studies report dye degradation by these enzymes [16, 23]. Remazol Brilliant Blue $\mathrm{R}$ and Drimaren Blue X-3LR are anthracene and diazo dyes, respectively. These classes of reactive dyes are the most used in the textile industry and have been widely employed in many degradation studies $[14,16,21,23,24]$.

The enzymatic treatments are still not commonly used in the textile industries. As mentioned before, the high costs associated with biocatalysts production and application still hinder their use on large scale with environmental purposes. The high cost of importation is the main obstacle to the application of enzymes on large scale. The enzyme extraction from the residues of solid-state fermentation might be one alternative for low-cost enzyme use and consequently environmental biocatalysis consolidation.

Toyobo do Brazil LTDA produces the edible mushroom shimeji (Pleurotus ostreatus). This production generates a large volume of colonized residual waste, $300-500 \mathrm{~g}$ of residue per $100 \mathrm{~g}$ of mushroom produced, which could be used to obtain low-cost ligninolytic enzyme complex. Considering that the consumption of these mushrooms has been increasing annually, due to its nutraceutical properties, it is important to give an appropriate destination to these residues. Additionally, this procedure allows for the utilization of an agroindustrial residue to obtain an added value product and minimize industrial disposal.

This study aimed at obtaining an alternative and lowcost ligninolytic enzyme pool from an agroresidue from the commercial production of Pleurotus ostreatus and compares its utilization with a commercial laccase from Aspergillus oryzae in the decolourisation of four textile reactive dyes. Similar study previously reported showed a very promising action of peroxidases from shimeji in decolourisation of RBBR [14]. The value of the present work lies in the identification of significant laccase activity in agrowaste from commercial production of edible mushroom shimeji. Another aspect that also deserves mention is that when comparing the crude extract with the commercial enzyme, the first was more efficient in the degradation of the dyes studied. During the dye degradation study, the following parameters were evaluated: dye concentration, reaction time, absence or presence of ABTS mediator, and the source of laccase ( $P$. ostreatus extract or commercial A. oryzae). Chemical structures of the dyes studied and their respective wavelength are presented in Table 1.

\section{Material and Methods}

2.1. Dyes and Chemicals. Four reactive dyes, Drimaren Blue X-3LR (DMBLR), Drimaren Blue X-BLN (DMBBLN), Drimaren Rubinol X-3LR (DMR), and Drimaren Blue CL-R (RBBR), representing different chemical classes
(Table 1) were provided by Maria Candida Textile Industry LTDA, Paracambi, Rio de Janeiro, Brazil. 2,2'-azino-bis(3ethylbenzothiazoline-6-sulfonic acid) (ABTS-98\% purity), 2,4-dichlorophenol, and 4-aminoantipyrine were purchased from Sigma Chemical Co. (St. Louis, MO, USA). Filter paper (FP) (Whatman no. 2) was purchased from GE Healthcare Life Sciences (São Paulo, SP, Brazil). All other chemicals were analytical grade reagents. Commercial laccase produced by a genetically modified Aspergillus oryzae was kindly provided by Novozymes (Novozym 51003). This enzyme is a robust stable laccase used for lignin modification in pulp and paper industry.

2.2. Enzyme Extraction and Storage Stability. The laccase rich extract was obtained from Pleurotus ostreatus cultivation residues generated as waste from shimeji production in solidstate fermentation after harvest of this edible mushroom. These residues were kindly provided by Toyobo do Brasil LTDA.

The aforementioned residues were homogenised and kept at $28^{\circ} \mathrm{C}$ for twenty days before extraction. Extraction of $20 \mathrm{~g}$ of residue was carried out under agitation during 15 minutes using $100 \mathrm{~mL}$ of distilled water, $100 \mathrm{~mL}$ of $0.02 \mathrm{M}$ sodium-tartaric buffer $\mathrm{pH} 4.0$, or $100 \mathrm{~mL}$ of $0.02 \mathrm{M}$ sodiumphosphate buffer $\mathrm{pH}$ 6.0. The crude extracts obtained were filtered on filter paper (Whatman no. 2) and then divided and kept at $-18^{\circ} \mathrm{C}$ or $4^{\circ} \mathrm{C}$ to evaluate enzyme stability during storage. The remaining activities of laccase were monitored during 130 days. Standard deviations were less than $10 \%$.

2.3. Enzyme Assays. Laccase activity was determined spectrophotometrically according to a modified method of NikuPaavola and coworkers in 1990 [27], by monitoring the oxidation of ABTS at room temperature without agitation. The assay mixture contained $3 \mathrm{mM}$ of ABTS in $0.2 \mathrm{M}$ sodium-succinic buffer ( $\mathrm{pH} 4.5$ ) and $100 \mu \mathrm{L}$ of laccase rich extract from $P$. ostreatus or commercial laccase in appropriate dilution in a final volume of $2 \mathrm{~mL}$. Oxidation of ABTS was monitored at $436 \mathrm{~nm}\left(\xi_{436}=29300 \mathrm{M}^{-1} \mathrm{~cm}^{-1}\right)$.

Enzymatic activity of oxidases, which depend or not on peroxide, was also evaluated by using 2,4-dichlorophenol and 4-aminoantipyrine as substrates [28]. Oxidation reaction was measured at $510 \mathrm{~nm}$ during 90 seconds $\left(\xi_{510}=\right.$ $18500 \mathrm{M}^{-1} \mathrm{~cm}^{-1}$ ). Enzyme activity was expressed in International Units (IUs) as the amount of enzyme required to release $1 \mu \mathrm{mol}$ of product in 1 minute.

The presence of cellulases and proteases activities was also investigated $[29,30]$. These measurements were performed in the Laboratory of Enzyme TechnologyChemistry Institute of Federal University of Rio de Janeiro. Cellulases were measured because $P$. ostreatus was cultivated using sawdust as support. Proteases were also determined to evaluate the influence of proteases in laccases activity. The presence of cellulases and proteases was not found.

2.4. Comparative Study between the Crude Extract and Commercial Laccase. The decolourisation of four reactive 
TABLE 1: Chemical structure and properties of the four reactive dyes studied.

Name

Chemical structure

Drimaren Blue X-3LR (DMBLR)

Reactive blue 52

Molecular weight $=631.49$

$616 \mathrm{~nm}$;

CI Reactive Blue 52

[21]

Drimaren Blue X-BLN (DMBBLN)

Reactive blue 198

$626 \mathrm{~nm}$;

CI Reactive Blue 198

[25]<smiles>COc1ccc(S(=O)(=O)O)cc1N=Nc1c(S(=O)(=O)O)cc2cc(Nc3nc(N)nc(Cl)n3)ccc2c1O</smiles><smiles>CCCNc1nc(Cl)nc(Nc2ccc(OS(=O)(=O)O)cc2[N+](=O)[O-])n1</smiles>

Drimaren Rubinol X-3LR (DMR)

Reactive red 55

pyrimidine

$530 \mathrm{~nm}$

CI Reactive Red 55

[26]<smiles>[X]c1nc([X])c(Cl)c(NC(=O)c2ccccc2)n1</smiles>

$\mathrm{X}=\mathrm{Cl}$, or $\mathrm{F}$

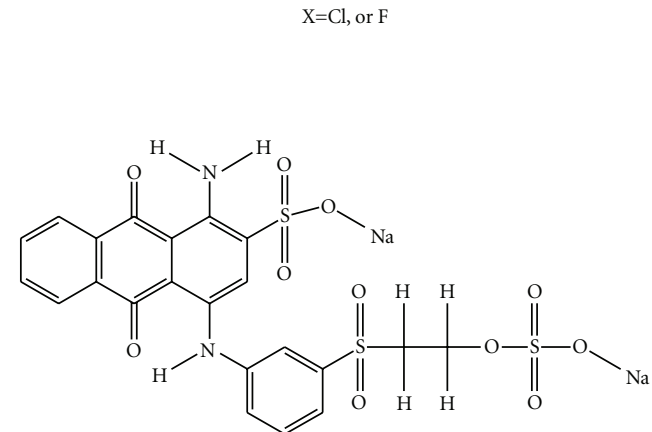

Drimaren Blue CL-R (RBBR)

Reactive blue 19

Molecular weight $=626.55$

$602 \mathrm{~nm}$;

CI Reactive Blue 19 (61200)

[21]

dyes was performed using crude extract and commercial laccase Novozym 51003.

Decolourisation reactions were carried out in a wide range of dye concentrations: 60, 120, and $240 \mathrm{ppm}$. The laccase activity in the reaction media was $0.02 \mathrm{IU} / \mathrm{mL}$ and, when it was necessary, $0.017 \mathrm{mM}$ of ABTS mediator was used. All reactions were performed at $\mathrm{pH}$ 4,0 (sodium tartarate buffer $0,2 \mathrm{M}$ ) without agitation. No changes in $\mathrm{pH}$ were observed during reactions. Dye decolourisation was measured spectrophotometrically after 1 and $24 \mathrm{~h}$ of reaction at the corresponding maximum absorption wavelength for each compound (DMBLR-616 nm; DMBBLN-626 nm; DMR $-530 \mathrm{~nm} ; \mathrm{RBBR}-602 \mathrm{~nm})$. All dyes concentrations were tested in similar conditions.

Additional study considering the decolourisation of a mixture of these four textile dyes was performed. In this case, the concentration of each dye was $60 \mathrm{ppm}$, and the crude extract in $\mathrm{pH} 4.0$ or commercial laccase was used in the absence (E) or presence (EM) of $0.017 \mathrm{mM}$ of ABTS. Laccase activity in reaction media was $0.016 \mathrm{IU} / \mathrm{mL}$. Degradation experiments were done in duplicate, and average values were reported. 


\section{Results}

3.1. Enzyme Extraction from Shimeji (P. ostreatus) Residues. Similar laccase activities $(255 \pm 5 \mathrm{IU} / \mathrm{mL})$ were found in the enzyme extraction from solid state fermentation residues using buffers or distilled water. Some hydrolases were also monitored, but only laccase showed expressive activity.

Figure 1 shows the laccase activity profile under refrigeration $\left(4^{\circ} \mathrm{C}\right)$ or frozen $\left(-18^{\circ} \mathrm{C}\right)$ during the storage study for 130 days. Extracts in $\mathrm{pH} 4.0, \mathrm{pH} 6.0$, and $\mathrm{H}_{2} \mathrm{O}$, kept at $4^{\circ} \mathrm{C}$, showed 47,51 , and $56 \%$ of remaining activities, respectively. The best stability result at $-18^{\circ} \mathrm{C}$ was found in the laccase rich preparation extracted with buffer $\mathrm{pH}$ 4.0, as no significant activity variation was detected after 75 days, and about $70 \%$ of the activity remained after 130 days. Frozen extracts in $\mathrm{pH} 6.0$ and $\mathrm{H}_{2} \mathrm{O}$ showed remaining activities of 36 and $44 \%$, respectively.

Considering the enzyme extraction, preliminary results showed that the extracts obtained at $\mathrm{pH} 6.0$ or distilled water presented lower decolourisation results compared to the crude enzyme extracted at pH 4.0 (data not shown). Considering the aforementioned results, the subsequent experiments for dye decolourisation were carried out using the laccase rich extract obtained at pH 4.0.

The stability of the ligninolytic complex is considered to be one of the determinant factors for the technical and economical viability of its industrial application to degradation of pollutants, as well as for the optimization of commercial enzyme production [31]. Therefore, the maintenance of enzymatic activity during storage is an important aspect. Previous studies [14] detected only 30\% of remaining activity in the extracts kept frozen after a 30-day period, and the extracts stored under refrigeration showed a progressive activity loss during an 80-day period. Differently from our work, the extracts obtained by Machado and Mateus presented higher stability under refrigeration [14]. These authors also observed an increase on the laccase activity in some extracts during the refrigeration or freezing preservation and suggested that the existence of inhibitory substances, only present in the initial phase after extraction, could justify this increase on the activity, which corroborates the results achieved in our stability studies. The ligninolytic pool obtained by Machado and Matheus [14] from Pleurotus ostreatus presented higher peroxidases activities, and these peroxidases were also responsible for RBBR decolourisation. In the present work, only laccases showed significant activities, and it is important to mention that different parts and different times of the cultivation were approached in each study, demonstrating the potential source of enzymes.

3.2. Dye Oxidation Catalysed by Laccases. All reactions were carried out in $\mathrm{pH} 4.0$ in accordance with preliminary results and literature $[14,18]$. Table 2 summarizes the percentages of colour removal obtained employing reactive dyes DMBLR, DMBBLN, DMR, and RBBR in the following concentrations: 60,120 , and 240 ppm, using enzymatic extract of $P$. ostreatus in $\mathrm{pH} 4.0$ in the absence (E) or presence of ABTS mediator (EM). The maximum wavelength of each dye was monitored during all reactions, and the decolourisation percentage was determined by the difference from initial and final absorbance. The decolourisation of DMBLR was observed in all concentrations studied, achieving values higher than $85 \%$ in $1 \mathrm{~h}$ and $97 \%$ in $24 \mathrm{~h}$ of reaction in the absence of ABTS mediator. Similar results were found for DMBBLN, solutions with $80 \%$ of decolourisation were obtained after $24 \mathrm{~h}$ also in the absence of ABTS. These results indicated that laccases produced by $P$. ostreatus are efficient in colour removal of DMBLR and DMBBLN solutions in the absence of ABTS mediator.

On the other hand, the use of ABTS mediator was essential in the DMR decolourisation. It was possible to achieve more than $86 \%$ of DMR colour removal after $1 \mathrm{~h}$ in concentrations lower than $240 \mathrm{ppm}$. The presence of ABTS also increased the decolourisation of RBBR by the laccase rich extract. The colour removal was improved from $61 \%$ to $90 \%$ and from $57 \%$ to $82 \%$ after $24 \mathrm{~h}$ using dye concentrations of 60 and $120 \mathrm{ppm}$ in the absence and presence of ABTS, respectively.

Table 3 summarizes the decolourisation values of reactive dyes DMBLR, DMBBLN, DMR, and RBBR, in the following concentrations: 60, 120, and 240 ppm, using commercial laccase in the absence (E) or presence of ABTS mediator (EM). In the DMBLR decolourisation reaction, the presence of ABTS was not necessary. This dye showed more than 95\% of colour removal after 1 hour. The presence of ABTS was fundamental for the DMR and RBBR. The colour removal of DMR dye incubated for 1 hour with commercial laccase was higher than the $80 \%$ at 60,120 , and $240 \mathrm{ppm}$. Similar results were found testing RBBR dye; however, it was necessary to have $24 \mathrm{~h}$ of incubation. About $80 \%$ of DMBBLN decolourisation was achieved using both enzymes preparations, even in the presence of the ABTS mediator.

Tables 2 and 3 show the percentage of colour removal of reactive dyes DMBLR, DMBBLN, DMR, and RBBR (60 ppm) in the presence of commercial laccase $(A$. oryzae) and laccase rich extract $(P$. ostreatus) in $\mathrm{pH}$ 4.0. Both enzymes preparations are able to catalyse the decolourisation of the dyes studied, but in several cases, DMBBLN presented relevant decolourisation using the laccase rich extract after $24 \mathrm{~h}$, around $80 \%$ of colour removal, while the commercial laccase did not provide satisfactory decolourisation percentage (approximately 60\% in $24 \mathrm{~h}$ ). DMBLR decolourisation with commercial laccase or laccase rich extract presented the best percentage of decolourisation, more than $95 \%$ in only $1 \mathrm{~h}$. The presence of ABTS was essential for the DMR and RBBR. The colour removal of DMR dye incubated for 1 hour with the crude extract or commercial laccase was higher than $80 \%$. RBBR showed higher values of colour removal (above $90 \%)$ in $24 \mathrm{~h}$, corroborating previous works $[14,24]$.

Many studies have shown that fungi or their enzymes are able to decolourise and detoxify industrial dyes [5, 15, 23]. It is not novel that $P$. ostreatus produces laccases effective for decolourisation of reactive dyes; however, the value of this report lies in the identification of significant activity in agrowaste from commercial production of edible mushroom shimeji. In general, dyes decolourisation catalysed by crude extracts or purified laccases obtained from white-rot fungi 
TABLE 2: Colour removal of the reactive dyes DMBLR, DMBBLN, DMR, and RBBR, after $1 \mathrm{~h}$ and $24 \mathrm{~h}$, in the presence of the crude enzymatic extract from shimeji (P. ostreatus) residues obtained in $\mathrm{pH} 4.0$ in the absence (E) or presence of ABTS mediator (EM). In bold the percentage of decolourisation over $70 \%$.

\begin{tabular}{|c|c|c|c|c|c|}
\hline \multirow{3}{*}{ Dyes } & \multirow{3}{*}{ Concentration (ppm) } & \multicolumn{4}{|c|}{ Colour Removal (\%) } \\
\hline & & \multicolumn{2}{|c|}{ Without ABTS } & \multicolumn{2}{|c|}{ With ABTS } \\
\hline & & 1 hour & 24 hours & 1 hour & 24 hours \\
\hline \multirow{3}{*}{ DMBLR } & 240 & 96.99 & 98.84 & 96.72 & 98.60 \\
\hline & 120 & 96.59 & 99.15 & 93.50 & 98.14 \\
\hline & 60 & 95.82 & 99.48 & 87.06 & 97.19 \\
\hline \multirow{3}{*}{ DMBBLN } & 240 & 68.02 & 82.01 & 66.06 & 80.68 \\
\hline & 120 & 68.34 & 83.62 & 65.96 & 79.43 \\
\hline & 60 & 66.26 & 83.97 & 57.54 & 74.11 \\
\hline \multirow{3}{*}{ DMR } & 240 & 26.70 & 66.03 & 86.33 & 94.07 \\
\hline & 120 & 27.88 & 69.14 & 94.97 & 93.46 \\
\hline & 60 & 38.35 & 66.25 & 92.56 & 91.04 \\
\hline \multirow{3}{*}{ RBBR } & 240 & 23.97 & 57.14 & 33.35 & 72.47 \\
\hline & 120 & 33.71 & 57.51 & 36.16 & 82.30 \\
\hline & 60 & 36.29 & 61.20 & 36.68 & 90.17 \\
\hline
\end{tabular}

TABLE 3: Colour removal of the reactive dyes DMBLR, DMBBLN, DMR, and RBBR, after $1 \mathrm{~h}$ and $24 \mathrm{~h}$, in the presence of the commercial laccase from Aspergillus orizae in the absence (E) or presence of ABTS mediator (EM). In bold the percentage of decolourisation over 70\%.

\begin{tabular}{|c|c|c|c|c|c|}
\hline \multirow{3}{*}{ Dyes } & \multirow{3}{*}{ Concentration (ppm) } & \multicolumn{4}{|c|}{ Colour Removal (\%) } \\
\hline & & \multicolumn{2}{|c|}{ Without ABTS } & \multicolumn{2}{|c|}{ With ABTS } \\
\hline & & 1 hour & 24 hours & 1 hour & 24 hours \\
\hline \multirow{3}{*}{ DMBLR } & 240 & 97.50 & 98.90 & 96.10 & 98.00 \\
\hline & 120 & 97.00 & 98.70 & 92.40 & 96.60 \\
\hline & 60 & 96.90 & 98.90 & 84.70 & 93.30 \\
\hline \multirow{3}{*}{ DMBBLN } & 240 & 30.60 & 57.40 & 32.40 & 59.30 \\
\hline & 120 & 31.20 & 59.80 & 31.00 & 61.80 \\
\hline & 60 & 31.70 & 63.00 & 23.80 & 62.90 \\
\hline \multirow{3}{*}{ DMR } & 240 & 0.30 & 1.00 & 79.70 & 91.70 \\
\hline & 120 & 3.50 & 3.50 & 90.50 & 89.70 \\
\hline & 60 & 1.00 & 3.30 & 84.90 & 87.90 \\
\hline \multirow{3}{*}{ RBBR } & 240 & 29.70 & 44.00 & 48.00 & 79.90 \\
\hline & 120 & 33.00 & 57.10 & 72.30 & 94.40 \\
\hline & 60 & 31.00 & 64.40 & 74.20 & 95.70 \\
\hline
\end{tabular}

has been most efficient using $\mathrm{pH}$ ranging from 3.0 to 5.0 [32]. Michniewicz and coworkers [23] investigated the $\mathrm{pH}$ effects in the decolourisation of Acid Blue 62, Acid Blue 40, Reactive Blue 81, Direct Black 22, and Acid Red 27, using laccases isoforms from Cerrena unicolor. Laccase I isoform kept 75\% of activity in the $\mathrm{pH}$ range of 2.5 to 5.0 , while laccase II isoform presented higher activity in $\mathrm{pH} 3.0$, decreasing its activity as $\mathrm{pH}$ values increased. Machado and Matheus [14] carried out experiments of RBBR decolourisation using $P$. ostreatus crude extract, cultivated for 25 days, aiming to evaluate the most suitable $\mathrm{pH}$ ranging from 3.0 to 7.0. The best decolourisation results were achieved at $\mathrm{pH} 4.0$, corroborating the results presented in Tables 2 and 3 .

The dye RBBR has been widely used as model compound in decolourisation studies [14]. Previous studies developed in our research group (data in press) also showed a very promising action of horseradish peroxidase. This plant enzyme was able to remove $95 \%$ of the RBBR colour in a solution containing $120 \mathrm{ppm}$ of this dye in 5 minutes of reaction.

Palmieri and coworkers [16] reported that RBBR decolourisation mediated by extracellular enzymes from $P$. ostreatus was dependent on reaction media conditions such as temperature, $\mathrm{pH}$, and enzyme concentration. The fungi $P$. ostreatus was able to decolourise more than $90 \%$ of RBBR with 3 days at low $(5 \mu \mathrm{M})$ and with 6 days at high $(50 \mu \mathrm{M})$ dye concentration. These authors also observed a reduction in toxicity of $95 \%$ after decolourisation reactions considering the inhibition of the bacterium Bacillus cereus in the presence of the dyes before and after treatment.

RBBR decolourisation was also studied using laccases from Trametes versicolor and HBT as mediator [24]. In this study, $40 \%$ of RBBR decolourisation was achieved applying free laccases and HBT after 30 minutes and 


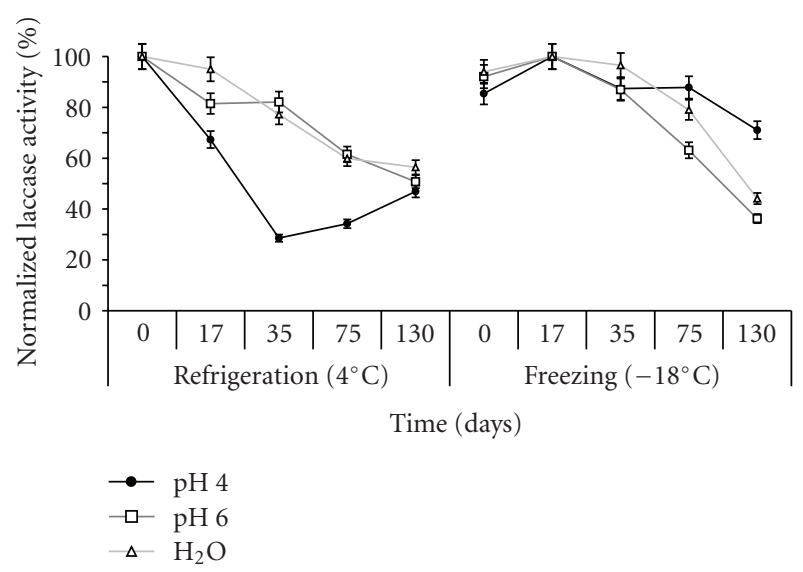

FIGURE 1: Laccase activity profile during 130 days. Extracts prepared in $\mathrm{pH} 4.0, \mathrm{pH} 6.0$, or distilled water preserved under refrigeration or freezing.

$70 \%$ of RBBR decolourisation after $2 \mathrm{~h}$, with immobilised laccases.

Özsoy and coworkers [21] compared Drimaren Blue X3LR (DMBLR) and Remazol Brilliant Blue R (RBBR) degradation mediated by two different fungi, Phanerochaete chrysosporium and Funalia troggi, and demonstrated that colour removal efficiency varies according to the microorganism. P. chrysosporium provided $11-20 \%$ of decolourisation after 10 days, while $F$. troggi was able to decolourise $92-98 \%$ of both dyes in a period of $4-10 \mathrm{~h}$. Erkut and coworkers [33] also reported the differences found among Funalia trogii, Coriolus versicolor, and Pleurotus ostreatus in decolourisation reactions of Drimaren Blue CL- BR (DB) and Remazol Brilliant Blue R (RBBR) under static conditions, with $30^{\circ} \mathrm{C}$ of temperature and $\mathrm{pH}$ 5.0; F. trogii removed about $90 \%$ of colour of both RBBR and DB dyes after $48 \mathrm{~h}$.

Ciullini and coworkers [34] studied decolourisation levels of six different classes of dyes. In all reaction media, the concentration of the different dyes was $500 \mathrm{mg} / \mathrm{L}$, and laccase activity was kept equal to $1.5 \mathrm{IU} / \mathrm{mL}$. Chromocomplexed azo, diazo, and anthraquinonic dyes presented percentages of colour removal higher than $85 \%$; however, monoazo and diazo achieved only $17-28 \%$. Other studies emphasizing the influence of chemical structure in the recalcitrance of certain dyes have been well documented. Nozaki and coworkers [35] tested 27 dyes from 6 different classes and showed the difference of two monoazo dyes decolourisation with similar chemical structures of Acid orange 20 (AO20) and 7 (AO7). The first presented about $71-100 \%$ of decolourisation and the second only $20 \%$.

Hou and coworkers [36] studied the decolourisation of an antraquinone dye also using a crude extract from $P$. ostreatus (strain 32). The dye concentration in the reaction mixture was $100 \mathrm{ppm}, \mathrm{pH} 4.5$, at temperature of $50^{\circ} \mathrm{C}$ and $30 \mathrm{IU} / \mathrm{mL}$ of laccase activity (in terms of ABTS substrate). The results showed that $70 \%$ of decolourisation was obtained when only the crude extract was employed and $90 \%$ using crude extract in the presence of $0.16 \%$ of ABTS after $5 \mathrm{~h}$ of reaction.

Comparing the colour removal results using laccase rich extract from $P$. ostreatus residues and the aforementioned results from literature, it was possible to obtain a close or high decolourisation percentage of the studied dyes. The reaction media employed in the present work contained only $0.02 \mathrm{IU} / \mathrm{mL}$ of laccase activity, approximately 30 times lower than laccase activity values reported by previous studies $[8,16,24,35]$. Our work emphasized the use of a temperature close to room temperature, that is, $35^{\circ} \mathrm{C}$, in order to minimise energy consumption. We also used a range of dyes concentrations from 60 to $240 \mathrm{ppm}$, and even acting in a concentration 4 times higher than the initial concentration $(60 \mathrm{ppm})$, the colour removal of the studied dyes was not affected, indicating the enzyme efficiency in a broad range of dye concentration.

3.3. Enzymatic Decolourisation of a Mixture of Dyes. In general, effluents from textile industries contain a mixture of dyes and auxiliary substances used during the dyeing process. The decolourisation of a mixture containing the four textile dyes was also evaluated. The absorption spectrum of the reaction mixtures containing $60 \mathrm{ppm}$ of each dye, with the laccase rich extract in the absence (E) or presence of ABTS (EM), and with the commercial laccase in the absence (E) or presence of ABTS (EM), was presented in Figures 2 and 3, respectively.

The laccase rich extract was able to perform a more effective decolourisation (Figure 2) when compared to the commercial laccase (Figure 3). The decolourisation of the mixture with crude extract, with or without ABTS, was higher than $70 \%$ in the maximum absorption.

Although the commercial laccase was effective in the decolourisation of DMBLR, DMR, and RBBR, the results of colour removal in the dye mixture showed a lower percentage when compared to the crude extract. This result could be explained by the occurrence of some interactions among the dyes or probably by the remaining DMBBLN contribution.

\section{Conclusions}

The present study showed the utilization of an agroindustrial residue to obtain a product with a high added value. This procedure also minimizes industrial disposal. The laccase rich extract presents an enzymatic pool with broad catalytic action, and it was prepared without purification or stabilization steps in order to obtain a low-cost biocatalyst. The decolourisation efficiency of reactive dyes in the presence of the laccase rich extract was similar or even better than the commercial laccase although we used a laccase activity 30 times lower than the values previously reported in the literature.

Important results related to reactive dyes decolourisation were obtained, and the use of ABTS was relevant only for the decolourisation of DMR and RBBR dyes using both laccases. Although the temperatures used in decolourisation reactions reported in the literature vary from 40 to $50^{\circ} \mathrm{C}$, 


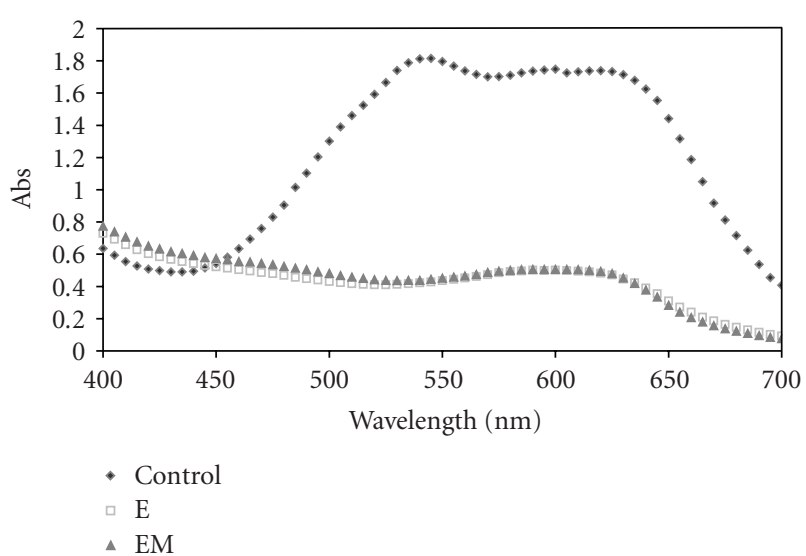

FIGURE 2: Absorption spectra of the mixture of the four dyes studied DMBLR, DMBBLN, DMR, and RBBR (60 ppm) before and after decolourisation reaction with crude extract in the presence (EM) and absence (E) of ABTS mediator.

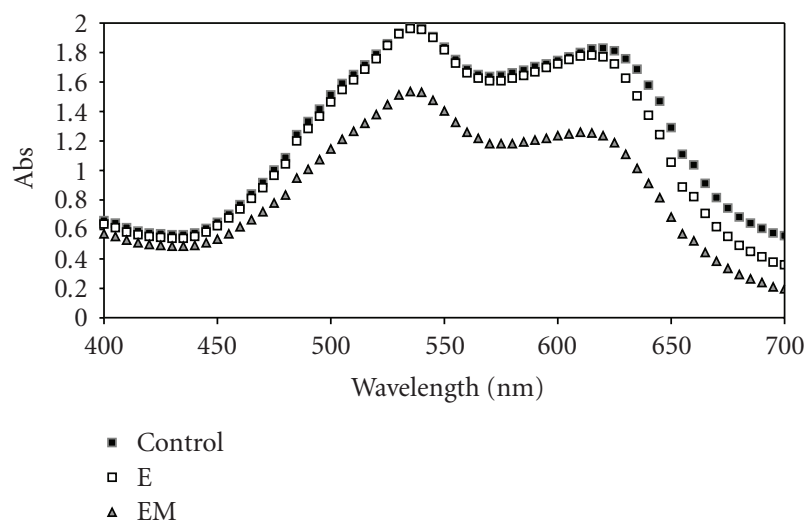

FIGURE 3: Absorption spectra of the mixture of the four dyes studied DMBLR, DMBBLN, DMR, and RBBR (60 ppm) before and after decolourisation reaction with commercial laccase in the presence (EM) and absence (E) of ABTS mediator.

the temperature of $35^{\circ} \mathrm{C}$, which was applied during our studies, proved to be efficient as well. This data is also important to preserve or minimize energy consumption. The enzymatic extract from P. ostreatus was more efficient in the decolourisation of the mixture of dyes than the commercial from A. oryzae.

Our work has demonstrated that the use of an industrial waste to obtain an enzymatic complex could be economically interesting and also contribute with an ecofriendly alternative. Future studies should test this enzymatic pool combined with other types of treatment to remove colour from textile industries wastewater.

\section{Acknowledgments}

The authors would like to thank CNPq for the financial support and Toyobo do Brasil for providing shimeji residues.

\section{References}

[1] D. J. Joo, W. S. Shin, J.-H. Choi et al., "Decolorization of reactive dyes using inorganic coagulants and synthetic polymer," Dyes and Pigments, vol. 73, no. 1, pp. 59-64, 2007.

[2] G. Akkaya, I. Uzun, and F. Güzel, "Kinetics of the adsorption of reactive dyes by chitin," Dyes and Pigments, vol. 73, no. 2, pp. 168-177, 2007.

[3] N. Durán and E. Esposito, "Lignin biodegradation and effluent treatment by ligninolytic fungi," in Microbiologia Ambiental, I. S. De Melo and J. L. Acevedo, Eds., p. 269, CNPMA/EMBRAPA, São Paulo, Brazil, 1997.

[4] N. Durán, "The impact of biotechnology in the pulp and paper industry: state of art," in Progress in Ecology, M. T. Martins et al., Ed., p. 543, Brasil Microbiol/ICOME, São Paulo, Brazil, 1997.

[5] A. Ünyayar, M. A. Mazmanci, H. Ataçağ, E. A. Erkurt, and G. Coral, "A Drimaren Blue X3LR dye decolorizing enzyme from Funalia trogii: one step isolation and identification," Enzyme and Microbial Technology, vol. 36, no. 1, pp. 10-16, 2005.

[6] M. Gavrilescu and Y. Chisti, "Biotechnology-a sustainable alternative for chemical industry," Biotechnology Advances, vol. 23, no. 7-8, pp. 471-499, 2005.

[7] M. C. Cammarota and D. M. G. Freire, "A review on hydrolytic enzymes in the treatment of wastewater with high oil and grease content," Bioresource Technology, vol. 97, no. 17, pp. 2195-2210, 2006.

[8] T. Robinson, B. Chandran, and P. Nigam, "Studies on the production of enzymes by white-rot fungi for the decolourisation of textile dyes," Enzyme and Microbial Technology, vol. 29, no. 8-9, pp. 575-579, 2001.

[9] G. M. B. Soares, M. T. P. De Amorim, and M. Costa-Ferreira, "Use of laccase together with redox mediators to decolourize Remazol Brilliant Blue R,” Journal of Biotechnology, vol. 89, no. 2-3, pp. 123-129, 2001.

[10] M. A. Mazmanci, A. Ünyayar, and H. I. Ekiz, "Decolorization of Methylene Blue by white rot fungus Coriolus versicolor," FEBS Letters, vol. 11, no. 5, pp. 254-258, 2002.

[11] L. Levin, A. Viale, and A. Forchiassin, "Degradation of organic pollutants by the white rot basidiomycete Trametes trogii," International Biodeterioration and Biodegradation, vol. 52, no. 1, pp. 1-5, 2003.

[12] K. Selvam, K. Swaminathan, and K.-S. Chae, "Decolourization of azo dyes and a dye industry effluent by a white rot fungus Thelephora sp," Bioresource Technology, vol. 88, no. 2, pp. 115119, 2003.

[13] A. D. Singh, N. Abdullah, and S. Vikineswary, "Optimization of extraction of bulk enzymes from spent mushroom compost," Journal of Chemical Technology and Biotechnology, vol. 78, no. 7, pp. 743-752, 2003.

[14] K. M. G. Machado and D. R. Matheus, "Biodegradation of Remazol brilliant blue R by ligninolytic enzymatic complex produced by Pleurotus ostreatus," Brazilian Journal of Microbiology, vol. 37, no. 4, pp. 468-473, 2006.

[15] K. Murugesan, I.-H. Nam, Y.-M. Kim, and Y.-S. Chang, "Decolorization of reactive dyes by a thermostable laccase produced by Ganoderma lucidum in solid state culture," Enzyme and Microbial Technology, vol. 40, no. 7, pp. 16621672, 2007.

[16] G. Palmieri, G. Cennamo, and G. Sannia, "Remazol Brilliant Blue $\mathrm{R}$ decolourisation by the fungus Pleurotus ostreatus and its oxidative enzymatic system," Enzyme and Microbial Technology, vol. 36, no. 1, pp. 17-24, 2005. 
[17] C. F. Thurston, "The structure and function of fungal laccases," Microbiology, vol. 140, no. 1, pp. 19-26, 1994.

[18] P. Giardina, G. Palmieri, A. Scaloni et al., "Protein and gene structure of a blue laccase from Pleurotus ostreatus," Biochemical Journal, vol. 341, no. 3, pp. 655-663, 1999.

[19] Á. T. Martínez, M. Speranza, F. J. Ruiz-Dueñas et al., "Biodegradation of lignocellulosics: Microbial, chemical, and enzymatic aspects of the fungal attack of lignin," International Microbiology, vol. 8, no. 3, pp. 195-204, 2005.

[20] R. Bourbonnais and M. G. Paice, "Oxidation of non-phenolic substrates. An expended role for laccase in lignin biodegradation," FEBS Letters, vol. 267, no. 1, pp. 99-102, 1990.

[21] H. D. Özsoy, A. Ünyayar, and M. A. Mazmanci, "Decolourisation of reactive textile dyes Drimarene Blue X3LR and Remazol Brilliant Blue R by Funalia trogii ATCC 200800," Biodegradation, vol. 16, no. 3, pp. 195-204, 2005.

[22] Y. Liu, J. Huang, and X. Zhang, "Decolorization and biodegradation of remazol brilliant blue R by bilirubin oxidase," Journal of Bioscience and Bioengineering, vol. 108, no. 6, pp. 496-500, 2009.

[23] A. Michniewicz, S. Ledakowicz, R. Ullrich, and M. Hofrichter, "Kinetics of the enzymatic decolorization of textile dyes by laccase from Cerrena unicolor," Dyes and Pigments, vol. 77, no. 2, pp. 295-302, 2008.

[24] P. Peralta-Zamora, C. M. Pereira, E. R. L. Tiburtius et al., "Decolorization of reactive dyes by immobilized laccase," Applied Catalysis B, vol. 42, no. 2, pp. 131-144, 2003.

[25] V. C. Almeida, W. F. Costa, J. Nozaki, and C. C. Oliveira, "Spectrophotometric determination of blue procion HEGN in effluents of textile industry exploiting the dye aggregation effect and flow injection analysis," Analytical Sciences, vol. 22, no. 3, pp. 445-448, 2006.

[26] R. M. El-Shishtawy, M. M. Kamel, H. L. Hanna, and N. S. E. Ahmed, "Ultrasonic-assisted dyeing: II. Nylon fibre structure and comparative dyeing rate with reactive dyes," Polymer International, vol. 52, no. 3, pp. 381-388, 2003.

[27] M. L. Niku-Paavola, L. Raaska, and M. Itävaara, "Detection of white-rot fungi by a non-toxic stain," Mycological Research, vol. 94, pp. 27-31, 1990.

[28] D. C. Yee and T. K. Wood, "2,4-Dichlorophenol degradation using Streptomyces viridosporus T7A lignin peroxidase," Biotechnology Progress, vol. 13, no. 1, pp. 53-59, 1997.

[29] T. K. Ghose, "Measurement of cellulase activities," Pure \& Applied Chemistry, vol. 59, pp. 257-268, 1987.

[30] J. Charney and R. M. Tomarelli, "A colorimetric method for the determination of proteolytic activity of duodenal juice," Journal of Biological Chemistry, vol. 171, pp. 501-505, 1947.

[31] M. D. Aitken and R. L. Irvine, "Stability testing of ligninase and Mn-peroxidase from Phanerochaete chrysosporium," Biotechnology and Bioengineering, vol. 34, no. 10, pp. 12511260, 1989.

[32] T. Deveci, A. Unyayar, and M. A. Mazmanci, "Production of Remazol Brilliant Blue R decolourising oxygenase from the culture filtrate of Funalia trogii ATCC 200800," Journal of Molecular Catalysis B: Enzymatic, vol. 30, no. 1, pp. 25-32, 2004.

[33] E. A. Erkurt, A. Ünyayar, and H. Kumbur, "Decolorization of synthetic dyes by white rot fungi, involving laccase enzyme in the process," Process Biochemistry, vol. 42, no. 10, pp. 1429$1435,2007$.

[34] I. Ciullini, S. Tilli, A. Scozzafava, and F. Briganti, "Fungal laccase, cellobiose dehydrogenase, and chemical mediators:
Combined actions for the decolorization of different classes of textile dyes," Bioresource Technology, vol. 99, no. 15, pp. 70037010, 2008.

[35] K. Nozaki, C. H. Beh, M. Mizuno et al., "Screening and investigation of dye decolorization activities of basidiomycetes," Journal of Bioscience and Bioengineering, vol. 105, no. 1, pp. 69-72, 2008.

[36] H. Hou, J. Zhou, J. Wang, C. Du, and B. Yan, "Enhancement of laccase production by Pleurotus ostreatus and its use for the decolorization of anthraquinone dye," Process Biochemistry, vol. 39, no. 11, pp. 1415-1419, 2004. 

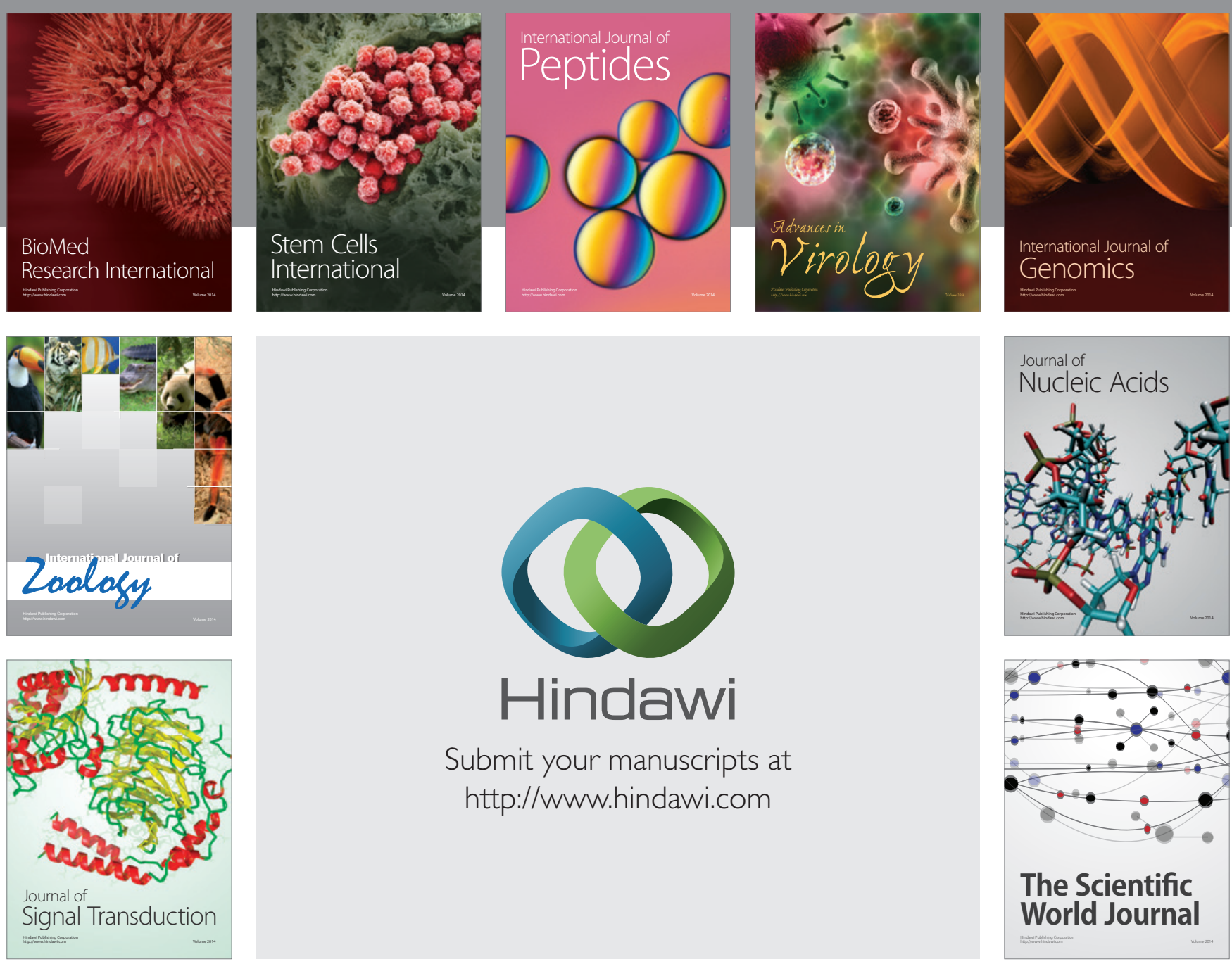

Submit your manuscripts at

http://www.hindawi.com
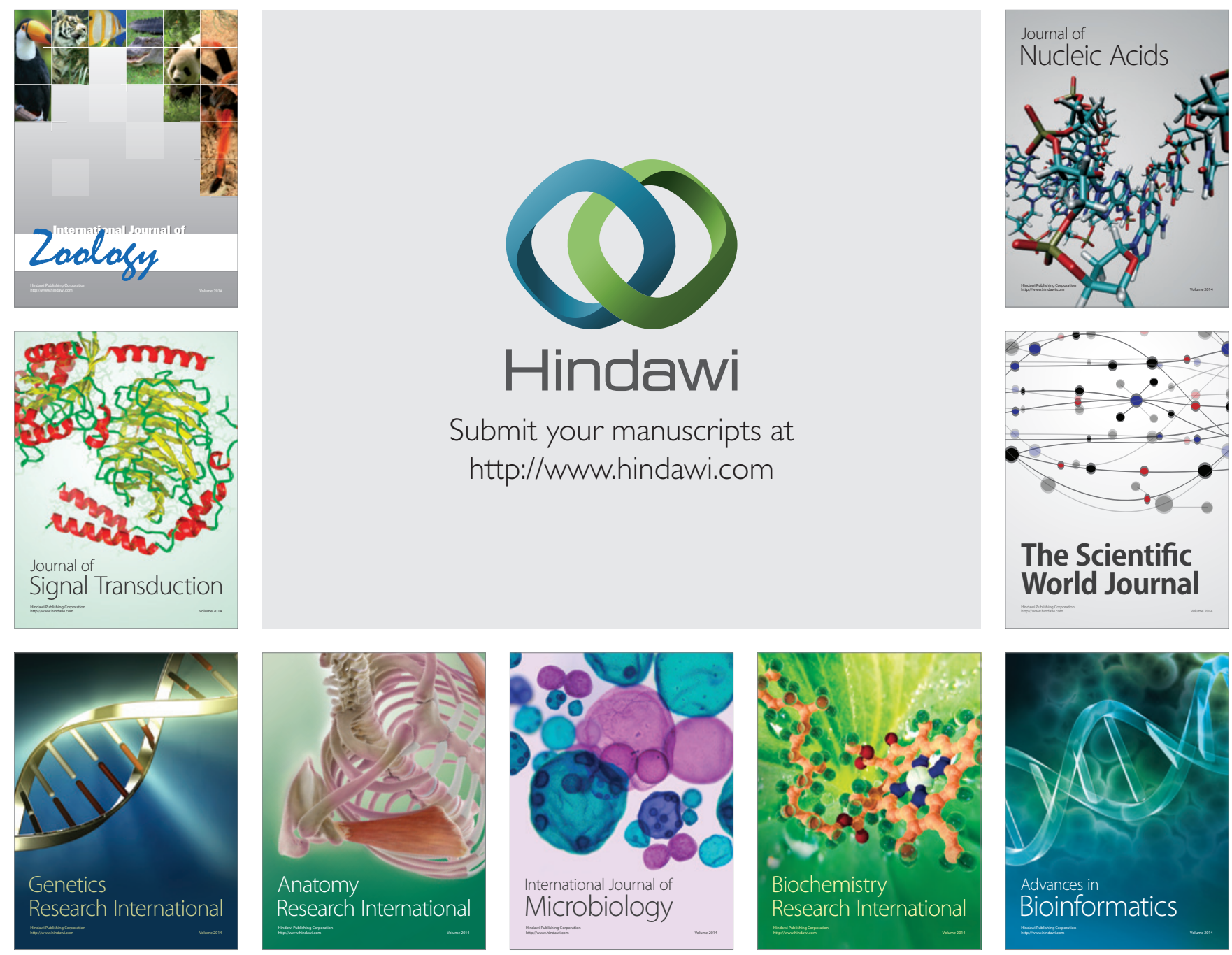

The Scientific World Journal
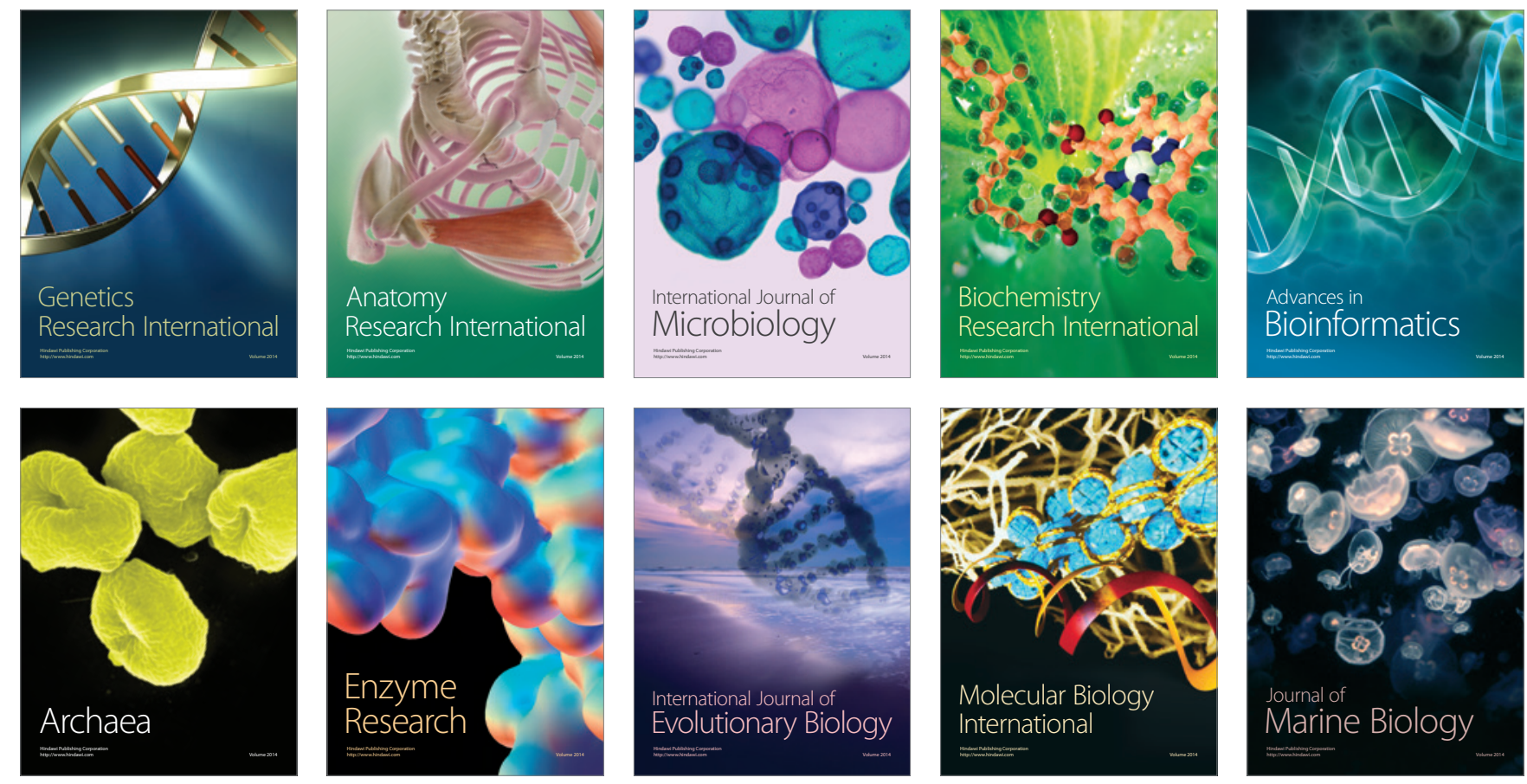